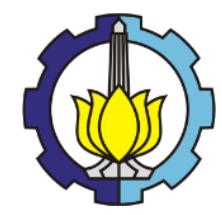

$8^{\text {th }}$ International Conference on Architecture Research and Design (AR+DC)

November 1-2, 2016

\title{
Defining distinctiveness aspect of place identity in urban heritage tourism
}

\author{
Nurlisa Ginting ${ }^{\mathrm{a}^{*}}$, Julaihi Wahid ${ }^{\mathrm{b}}$ \\ ${ }^{a}$ Departement of Architecture, Faculty of Engineering, University of Sumatera Utara, 9 Dr. T. Mansur Street, Medan, 20155, Indonesia \\ ${ }^{b}$ School of Housing Building and Planning, University of Sains Malaysia, Gelugor, Penang, 11800, Malaysia \\ *Corresponding author. Tel.: +62811608102; fax: +62 618219525 . \\ E-mail address:nurlisa@usu.ac.id
}

\begin{abstract}
In supporting heritage tourism, emotional and psychological reactions between people and the places are required until the sites are no longer a mere identity of the geographical formation. The positive perception of people indicates satisfaction that is strongly influenced by the image of an urban area. The image defines the character of the place (spirit of place). In shaping the image of place, place identity takes a significant role and distinctiveness is one aspect of it that contributes in. This research aims to investigate the distinctiveness aspect and its influences in defining place identity of urban heritage area by using variable, i.e. landmark, uniqueness, particular character, and different perception. It focuses on the historical corridor of Medan City, Indonesia, chosen due to its significant role in the establishment of Medan City in past and the existence of historic buildings. This research combined qualitative and quantitative method through field observation and nine in-depth interviews as well as 360 questionnaires distribution, respectively to examine the perception of residents and visitors. This research contributes in defining place identity that can be used as evaluation and indicator for future planning. It will benefit in securing place identity towards support in urban heritage tourism that improves the quality of life. The result indicates that the existence of heritage buildings as landmark allows someone to have a unique affiliation to the research area. However, the diversity of interesting cultural activity, local product as well public facilities requires more improvement.
\end{abstract}

Keywords: urban heritage tourism; place identity; spirit of place; distinctiveness; Medan City

\section{Introduction}

In recent years, tourism becomes the multi-sector industry that rapidly grows and the largest resource of income for many countries (Zbuchea, 2008 in (Stratan, Perciun, \& Gribincea, 2015)), specifically developing countries to generate the economy (Samimi, Sadeghi, \& Sadeghi, 2011). It benefits in improving the quality of life of residents and visitors such as resting, relaxing, and increasing knowledge (Constanta, 2009 in (Ginting \& Wahid, 2015)). One type of tourism which grows in popularity, the most influential and fastest growing in the world, is the heritage tourism (Orbaşli, 2000) which provides a special experience in enjoying the past portrays.

The development of heritage tourism is supported by globalization where its successful depends on the number of tourists visiting the urban heritage area. One of the factors that could be an attraction in an urban heritage area is the image of an urban area where it can generate the satisfaction of visitors (Riza, Doratli, \& Fasli, 2012). A strong and identifiable image of an urban area would have a positive impact on the satisfaction of the visitors (Riza et al., 2012).

Moreover, an urban heritage has a tendency to reflect certain image which indicates the spirit of place to attract people come (Butler, Hall, \& Jenkins, 1998). To gain tourists' satisfaction requires emotional and psychological 
reactions between people and the place. Therefore, it is necessary for increasing not only tourist perception but also emotional and psychological reactions (Otto \& Ritchie, 1996). Moreover, an urban area should have peculiarities that distinguish from others. The peculiarities, indicating place identity (Orbaşli, 2000), include the uniqueness of the historic objects, historic buildings, cultural activity, and local products. The identity of an urban area will reflect the complexity of the culture that differs from other places (Ujang, 2012). It is closely related to the particular character of a place where the history will reflect the distinctiveness of the place (Kalandides, 2011).

\subsection{Issue and Objective}

Globalization has supported the development of tourism where people can easily get information, participate in various social life quickly and allow someone to travel around the world. This often leads to the standardization of tourism area. An urban tourism tends to modify or build modern building everywhere without awareness with the contextual environment surrounding or even sometimes destructs the heritage buildings.

This phenomenon also becomes an issue in Medan City where the research took a place. The physical changes due to the destruction of physical heritage buildings in Medan City have affected the image of an urban heritage. Moreover, the new buildings in the modern architecture have blurred the image as well and created the same scene everywhere (Jacobs, 2002) and as the consequence, it would lose the identity. The loss of identity will weaken meaning, attachment, and place experience (Ujang, 2012). Therefore, it is very paramount in keeping meaning and identity, the elements, and the image of an urban area. Some places are considered more important than elsewhere due to its physical elements and diversity of cultural activities.

There are many studies examined the relationship between heritage and identity, namely: Bessie're (1998); Chronis (2005); Palmer (1999, 2005); Pretest (2003), while the impact of heritage tourism to identity formation has also been investigated by Ashworth \& Larkham (1994); Bessie're (1998); (Doorne, Ateljevic, \& Bai, 2003); (Pritchard \& Morgan, 2001). However, only a few studies examined the effect of the place identity to the heritage tourism development and distinctiveness aspect, especially in Indonesia.

This research aims to investigate the distinctiveness as one of place identity aspects, and its influences in defining place identity of urban heritage area in a historic corridor in Medan City, Indonesia. This research contributes in defining place identity that can be used as evaluation and indicator for future planning. It will benefit in securing place identity towards support in urban heritage tourism that will create the image of the place and improve the quality of life of residents and visitors.

\section{Literature Review}

\subsection{Spirit of Place and Place Identity}

Place identity is the result of someone's response to the changes of the physical environment for maintaining the attachment and sense of pride of a place. The concept of identity associated with a place is called the place identity, and the first term was used in the 1970s (H. M. Proshansky, 1978). It is determined by the physical elements, meaning, and association developed between people and place (Bott et al., 2003 in (Wang \& Xu, 2015)). With an identity, as a concept of distinctiveness, an urban area is distinguishable from others.

In maintaining and preserving the identity and meaning of place, the image, character and meaning of a place should be familiar to people (Norberg-Schulz, 1980). The image of a place is a first strong impression about the uniqueness and not belongs to anywhere else. It was formed through the placement of inheritance objects or architectural elements including the supporting elements as well as the environment surrounding such as the material used to construct roads and surrounding buildings in the whole layout. Overall, the image of a place indicates an aspect which is known as the spirit of place (Genius Loci in Roman).

Spirit of place is the character of the place that plays a role in embedding the identity of an urban area and ultimately reflects the image of the urban area (Mutfianti, 2013). The image is the result of perception between people and the place. In forming the image, required identity, structure, and meaning that connects between the people and the object including the emotional meaning related to the objects (Lynch, 1960). The components are imageable in the mind map of someone. 


\subsection{Place Identity Aspect}

Place identity theory has been widely discussed to identify the identity of a place. Some of the research is Place Identity (Lalli, 1992; H. M. Proshansky, 1978; Harold M. Proshansky, Fabian, \& Kaminoff, 1983); Sense of Place or Rootedness (Buttimer, 1980; Relph, 1976; Tuan, 1980), Place Dependence (Stokols \& Shumaker, 1981), and Attachment to Place (Gerson et al., 1977; Altman \& Low, 1992). These studies reveal the relationship between people and the surrounding physical environment depending on the experiences of the person.

In the social psychology context, Breakwell $(1986,1992,1993)$ which further developed by Twigger-Ross and Uzzel developed a "model of identity". The identity is determined by two processes, namely the implementation of settlements and evaluation (Breakwell, 1986). The process is based on memory system that will absorb new elements (such as personal values, behaviors, or social and styles such as a corporation) and adjust the environment to such matters. Meanwhile, the evaluation process puts the values to the elements of identity. Both of these processes are guided by four principles, i.e., distinctiveness, continuity, self-esteem, and self-efficacy.

\subsubsection{Distinctiveness Aspect}

Distinctiveness refers to a place or a city that can be distinguished from other cities (Twigger-ross \& Uzzell, 1996). A place can be a component that distinguishes one person to another. In line with this concept, distinctiveness causes a person has a special affiliation with him/her and the environment that is clearly different from other kinds of affiliation (Twigger-ross \& Uzzell, 1996).

Distinctiveness is related to a positive perception of the uniqueness of a place (Lalli, 1992). It is visible from appearance, values of social experience, culture, and inheritance objects that will always be remembered or recorded by someone. Therefore, conservation of inheritance objects can help to create the character of a place. Moreover, the inheritance objects often become the element of place that distinguish with other places. A city is legible if it has urban spaces that are easily identified. Furthermore, a place has a distinct value when it has a landmark as a tool to distinguish it from other places (Lynch, 1960).

Distinctiveness is an important aspect in shaping the identity, particularly in an urban heritage. Therefore, a place that is "imageable" can help a person to distinguish a place to other places. (Lalli, 1992) used the term of "external evaluation" to reveal distinctiveness aspect. The theory described the comparative evaluation between one city and other cities in other place, with the particular character and the uniqueness of a place perceived by people. It is similar to the theory of Breakwell which described the uniqueness or particular character of a place (Breakwell, 1986).

By comparing the major theories of place identity: Breakwell (developed by (Lalli, 1992; Lynch, 1960; Twigger-ross \& Uzzell, 1996), the authors concluded that there are four variables to investigate distinctiveness aspect in defining place identity, i.e., landmark, uniqueness, and particular character, and recommend different perception as one of distinctiveness variables that reflect certain image of a place as well (Table 1).

Table 1. Variable of Distinctiveness Aspect

\begin{tabular}{|c|c|c|c|}
\hline \multicolumn{4}{|c|}{ Distinctiveness Aspect } \\
\hline Landmark & Uniqueness & Particular Character & Different perception \\
\hline
\end{tabular}




\section{Methodology}

\subsection{Research Area}

The research was conducted in 2012. Three areas located in the center of Medan city were chosen as the setting for this research. The areas comprise of the main tourist destination in Medan, namely Maimoon area, Kesawan area, and Merdeka Square Area (Figure 1). These areas were in historic corridor of an urban area which is one of the city's assets in the tourism sector (Jansen-Verbeke, 1986). Medan is historic city of Dutch colonialism and the glory of Malay Deli in the past (Buiskool, 2004). Inheritance objects including historic buildings with various architectural style stretch along the corridor.

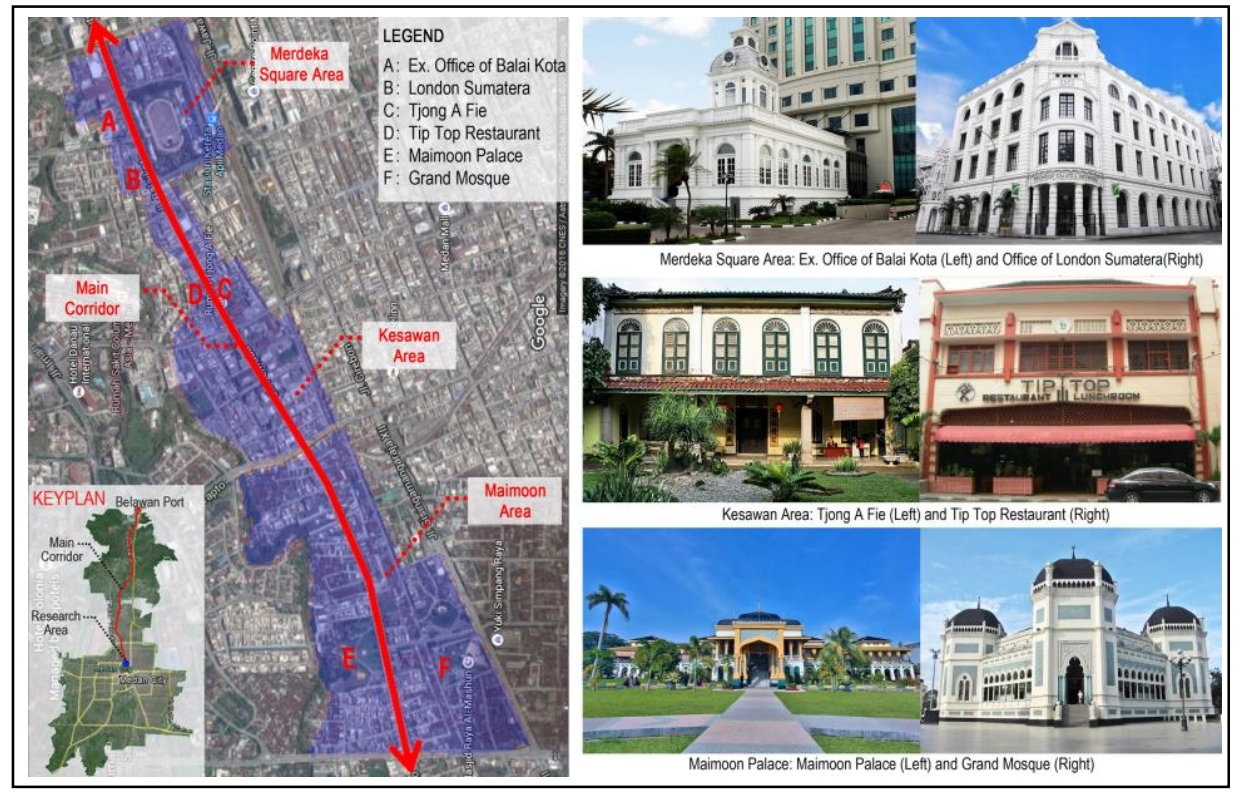

Fig. 1. Research Area

The places were chosen due to some criteria. The research area is the place where most of the heritage buildings protected by the Government of Medan City through the Regional Regulation. The heritage buildings in three places have a distinctive style based on the authority, Maimoon area indicates Malay style, while Chinese commercial shophouses laid out in Kesawan Area, and around Merdeka Square stretches out art deco and Renaissance buildings (offices, commercial and cultural center) that indicate Dutch colonial constitutional (Figure 1). The existence of unique historic buildings indicates the success of heritage tourism in a region (Ismagilova, Safiullin, \& Gafurov, 2015). Moreover, the places have distinctive historical value including culture, activities, and physical elements that reflect their authority in the colonial period. The distinction in the areas creates a unique image.

The areas are also the famous tourist destination that attracts many tourists in Medan City. It is proved by the existence of Maimoon Palace, Grand Mosque, Tjong A Fie, Tip Top Restaurant, as well as Merdeka Square is in brochures tourism that promotes Medan City and North Sumatera (Office of Culture and Tourism of Medan City, 2013). Besides that, the research area represents the establishment of Medan City. It lied out Katamaso St, Pemuda St, Ahmad Yani Kesawan St, and Balai Kota St that is the main corridor in Medan City Center which links the North-South Medan City (Figure 1) and pioneer of the use of land transportation in Medan City.

\subsection{The Method}


The result is based on the analysis of qualitative method enhanced by quantitative to examine respondents' perception including residents and tourists. The qualitative method was employed through field survey and nine indepth interviews. Periodic observation and photography are used as a technique for documentation of physical characteristics, types, and activity of users as well as alteration or destruction of heritage buildings. While face to face has been conducted with nine key respondents, consist of tourism stakeholders, buildings' owners, travels and hotels association, tourism business, humanist, and academia.

The quantitative data was done through 360 questionnaires distribution. The questionnaire is designed to obtain the desired information, namely profiles of respondents (age, gender, status, occupation); relevance to points (goals, intentions, frequency of visits, and duration); relevance to tourism (events or activities); and perception on the distinctiveness aspect (landmark, uniqueness, particular character, and different perception).

The questionnaire result is measured by using a Likert scale of 5 series; ranging from "strongly agree" to "strongly disagree." Approval of the respondents on a question is used to measure the attachment, attributes, and characteristics. In defining the place identity, Likert scale is often used (William, et.al, 1995; White et al., 2008; Jorgensen and Stedman, 2005; Hidalgo and Hernandez, 2001). In this research, Likert-scale questions structured open question is conducted to gather information and perception of respondents to the characteristic of the place. Negative responses are also discussed in an open question, although it is designed as a positive statement.

The data of qualitative and quantitative method were triangulated to find the convergence of results. The triangulation method is appropriately conducted in each layer phenomenon, converge of the results that provide information on other methods used and give new perspectives or conflict that expand the scope of the research (Creswell, 1994). Then, both methods were analyzed to complete the strengths and weaknesses. The qualitative data was identified based on the relating variables and the relationship between two or more variable and then processed by SPSS 20 while quantitative data needed aggregation and sorting to make the meanings clearer.

This research was conducted in an urban heritage area which has specific culture, attitudes, and behavior. So, the implementation of the result will be different in other places. Moreover, people tend to respond to their environment based on their experiences, structuring and information which is obtained from the place (Cheshmehzangi \& Heat, 2012). Thus, it became the limitation for this research.

\section{Result and Discussion}

\subsection{Respondents}

A total of 360 respondents is involved in this research. 120 respondents represent each area consisted local people (60) and tourist (60). The majority of respondents aged between $25-49$ years old where almost $55 \%$ of them are male. The result shows that the majority of residents is not from the local people outside the research area while the domestic and foreign tourists are more in Maimoon Area and Merdeka Square Area. Kesawan has a higher number of foreign tourist from Europe (Germany, Netherland, and America), while Asian tourist (Malaysia and Singapore) is more dominant in Maimoon Area and Merdeka Square area.

\subsection{Distinctiveness Aspect}

The direct experience experienced by someone will create opinion or perception. Someone's perception of a place will be different when the place has a particular character that will distinguish from others. A place that has the same object will certainly lead to boredom for people who go through it. Similarly, when the object found was same in other places. The existences of historic buildings provide the particular characteristic of a place that will lead to a distinctive place.

Based on the result, found that most respondents recognize the existence of heritage buildings in the research area is attractive (Table 2). So, it can be concluded that all the areas of research area have its distinction that different from other places (Figure 2).

In an urban area, distinctiveness is also formed due to the culture which is performed in a certain time. The culture can be an idea of decision-makers and people involved in. This is in line with Proshanky's theory (Harold M. 
Proshansky et al., 1983) which stated that place identity is a subculture of identity within a group of people which express their life on the physical environment. A place can reveal and affirm people's identity. So it becomes something natural that physical reality will be different to other places because it is strongly influenced by people's living in that place. The reality is the existence of historic buildings in the research area is the image of local culture developed in the period of Dutch East Indies.

Table 2. Respondents' perception of Distinctiveness Aspect in Research Area

\begin{tabular}{|c|c|c|c|c|c|c|}
\hline \multirow[b]{2}{*}{ Statement } & \multicolumn{2}{|c|}{ Maimoon Area } & \multicolumn{2}{|c|}{ Kesawan Area } & \multicolumn{2}{|c|}{ Merdeka Square Area } \\
\hline & $\begin{array}{l}\text { Residents } \\
\text { Mean }\end{array}$ & $\begin{array}{c}\text { Tourists } \\
\text { Mean }\end{array}$ & $\begin{array}{l}\text { Residents } \\
\text { Mean }\end{array}$ & $\begin{array}{c}\text { Tourists } \\
\text { Mean }\end{array}$ & $\begin{array}{c}\text { Residents } \\
\text { Mean }\end{array}$ & $\begin{array}{c}\text { Tourists } \\
\text { Mean }\end{array}$ \\
\hline A. It is easy to get here & 3.70 & 3.60 & 3.93 & 3.75 & 3.77 & 3.78 \\
\hline B. It is an attractive place & 3.50 & 3.57 & 3.78 & 3.48 & 3.72 & 3.82 \\
\hline C. Interesting historic buildings & 4.15 & 4.13 & 4.18 & 3.87 & 3.82 & 4.02 \\
\hline D. There are good places to eat & 3.43 & 3.73 & 3.77 & 3.78 & 3.60 & 3.92 \\
\hline E. Diversity of selling local product & 3.58 & 3.42 & 3.73 & 3.57 & 3.62 & 3.73 \\
\hline F. There are interesting cultural activities & 3.68 & 3.75 & 3.88 & 3.62 & 3.50 & 3.75 \\
\hline G. There are many facilities for visitors & 3.67 & 3.67 & 3.87 & 3.63 & 3.62 & 3.67 \\
\hline H. Landmark of Medan City & 4.12 & 4.07 & 4.20 & 4.02 & 4.05 & 4.15 \\
\hline Value Format: $1=$ strongly disagree, $5=$ strongly agree & 3.73 & 3,74 & 3.92 & 3.72 & 3.71 & 3.86 \\
\hline
\end{tabular}

\subsubsection{Landmark}

The research area is regarded the landmark of Medan City because it is easily identified by its cultural and historical values that is considered as the element of reference (Hussain \& Ujang, 2014). It also relates to the historical development of spatial structure and morphology of Medan city. It is proved by the result of questionnaires distribution: Maimoon Area, local people (4.12), tourists (4.07); Kesawan Area, local people (4.20), tourists (4.02); Merdeka Square, local people (4.05), tourists (4.15) (Table 2) that are easily recognized and made the distinctive place that become a tool that distinguish these areas from other areas in the city (Lynch, 1960). It is also supported by the depth interview with key respondents:

\footnotetext{
"The historic buildings have indirectly become the landmark of Medan City. For instance, we asked travelers going through the road or on vacation in Medan City, if we mention the ex. Office of Balai Kota, Tjong A Fie Mansion or Maimoon, travelers knew immediately that these historic buildings exist in Medan City. It can be concluded that the historic buildings become the landmark of the city".

(Key Respondent: Chairman of ASITA (Association of the Indonesian Tours and Travel Agent) of North Sumatera)
}

The existence of Merdeka Square and Maimoon Palace is regarded as the landmark of Medan city as well (Figure 2) due to the location in the center of Medan City. Merdeka Square is located at Balai Kota St, Medan City, known as the zero point of Medan City. This is supported by the results of the depth interview with key respondent, as follow:

\footnotetext{
"Merdeka Square already becomes the landmark of Medan City. When national celebration held at Merdeka Square, it certainly attracts lot of local people and tourist comes there. Because it is located in the center of Medan city, so it is easy to reach from anywhere and becomes initial sign of Medan City”. (Key Respondent: Chairman of INCCA (Indonesian Congress and Convention Association) of North Sumatera)
}

\footnotetext{
"Maimoon Palace is familiar as the landmark of Medan City. Many of my colleagues outside of Medan City, for example from Aceh, Padang, Jakarta, and Bandung visited there. They know Maimoon Palace well”. (Key Respondent: Department of Culture and Tourism of North Sumatera)
}

The accessibility in Kesawan Area, local people (3.93), tourists (3.75) and Merdeka Square, local people (3.77), tourists (3.78) (Table 2) received positive perception due to the existences of the landmark in the center of Medan city. In contrary, respondents are rather difficult to get to Maimoon area, local people (3.70) and tourist (3.60) (Table 2). It is in line with Lynch (1960) who stated that the existences of landmarks help people to orientate and access to finding a way. It is an initial sign that certainly influences people's imageability and memory of an 
urban area (Hussain \& Ujang, 2014). Hence, it can be concluded that the landmark of the primer elements of an urban tourism which should be managed and maintained properly (Jansen-Verbeke, 1986).

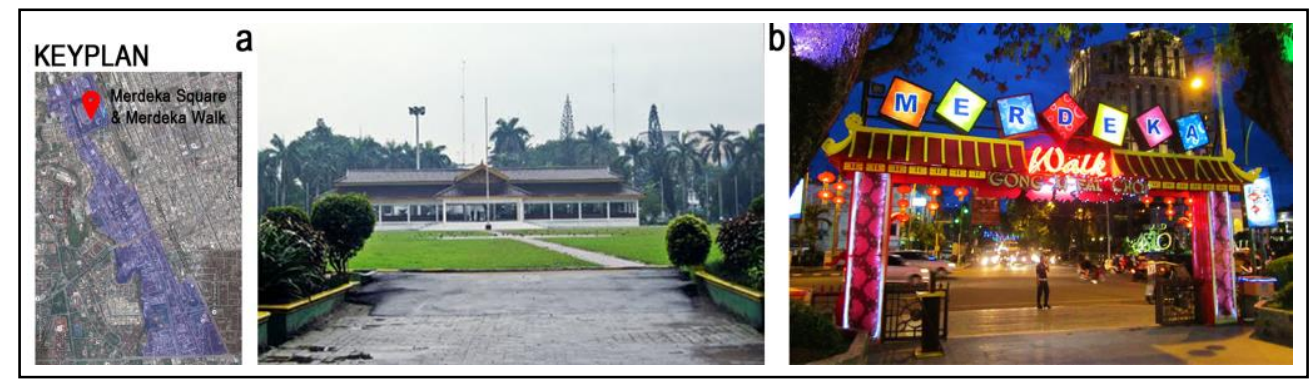

Fig. 2. (a) Merdeka Square; (b) Merdeka Walk

\subsubsection{Uniqueness}

Respondents assessed that the research area is feasible as the landmark of Medan City due to the uniqueness of historic buildings. They were truly impressed with the historic buildings with the various architectural styles. Its existence provides value and meanings to tourist (Shuib et al., 2008 in (Azhari \& Mohamed, 2012; Ginting \& Wahid, 2015)). Today, many cities are encouraged to preserve historic buildings because it reflects not only energy but also the spirit and identity of an urban area (Azhari \& Mohamed, 2012).

The existence of Maimoon palace and grand mosque (Figure 1) that is the unity of Islamic and European architecture becomes one of heritage tourism attraction for Medan city. The buildings show the influences of the authority of Europe in the past. This in in the line with the results of the questionnaire: Maimoon Area, local people (4.15), tourists (4.13); Kesawan Area, local people (4.18), tourists (3.87); Merdeka Square, local people (3.82), tourists (4.02) (Table 2) shows that respondents have a very strong reason to visit due to the interesting historic buildings that make this place has a distinctive feature so it easy for visitors to remember (Lalli, 1992).

Based on the perception of respondents, the research area has uniqueness through the interesting historic buildings and supported by the results of interviews with key respondents:

\footnotetext{
"Every heritage building is certainly fascinating because it reveals not only the story of its history but also the effect of the culture that played a role in shaping the story of a historical building. It makes each historic building unique and diverse between one another like Tjong A Fie, ex. Office of Balai Kota, Maimoon Palace, Grand Mosque, and the Post Office". (Key Respondent: Owner of Tjong A Fie)
}

It clearly shows that the existence of historic buildings is an important element because it has a strong identity to reveal the historical atmosphere and link to the past (Cheshmehzangi \& Heat, 2012; Paumier, 2004). It makes a place becomes dynamic and variant, full of meaning and experiences (Ginting \& Wahid, 2015) and reflects the local character of a place. This is in line with Paumier (Paumier, 2004) stated that image of a place would be strong and identified when it consists at least six elements, i.e. historic buildings, geography, landmarks, street landscaping, and public art. Therefore, the existence of historic buildings should be well-maintained due to its role in defining distinctiveness aspect. It is also expressed concisely by depth-interview:

\footnotetext{
"The most major tourism assets in Medan City is the historic buildings, there are Maimoon Palace, Grand Mosque, Tjong A Fie, London Sumatera Building, Tip Top Restaurant, ex. Office of Balai Kota, Indonesia Post Office, Merdeka Square. If the historic buildings are wellmaintained, they will be very attractive to domestic tourists and foreign tourists as well. So tourists are also pleased to see the fascinating historic building". (Key Respondent: Forum Manager Hotel)
}

A tendency to modify facade and build a modern building that contrasts with surrounding environment or even sometimes destruct the historic buildings certainly would influence image and perception of people. The visual elements of the facade would create the impression of a chaotic or unpleasant consequence. It could be same in architectural styles, forms the facade, the horizontal or vertical line, elements of the door (recurrence of the door, the 
door, and the door component), and window elements (recurrence of the windows, the windows, and the windows), color consisting of color type, color purity and brightness of colors, textures, adornments, and material. Over time, the uniqueness of the historic buildings will also fade. Therefore, the existence of historic buildings and its uniqueness should be preserved so it can create the uniqueness of an urban environment and provide visual comfort for the people. Rows of building facades that successfully provide visual comfort in the heritage area will certainly affect the formation of the identity of the place. Forming visual elements of the facade are important in generating an identity able to captivate tourists.

Furthermore, negative perception assessed by authors associated with the difficulty of finding attractive places: Maimoon Area, the local people (3:50), tourists (3:57); Kesawan Area, local people (3.78), tourists (3:48); Merdeka Square, local people (3.72), tourists (3.82) (Table 2). In supporting tourism, an attractive place can help a person to orientate and establish a sense of safety. Therefore, an urban area should be "imageable" so someone can make an imageable memory of the city.

\subsubsection{Particular Character}

Merdeka Square is the place for doing various social activities such as jogging and gathering with families. It is rounded by culinary delight in the west (Merdeka Square) (Figure 2). The tourists (3.92) regarded that Merdeka Square is a good destination for tourism due to the historic buildings, public green space in the center of Medan City, and the existence of culinary delight in Merdeka Walk. This is also supported with depth interview:

\footnotetext{
"Merdeka Square is an attractive place for tourist due to the existence of well-maintained historic buildings in the surrounding areas. We can take a long time just for sitting and eating here while staring at the historic buildings, so I often come here with my friends and my families." (Key Respondent: Humanist of North Sumatera)
}

However, less positive respondents got from local people (3.60). The perception of tourists and local people may be different. This supports the findings of White (White, Virden, \& van Riper, 2008) who stated that there are differences in perceptions between residents and tourists. They did not feel the same feeling in Merdeka Square as well as in Maimoon Area and Kesawan Area: Maimoon Area, local people (3.43), tourists (3.73) and Kesawan Area, local people (3.77), tourists (3.78) (Table 2). They expressed the difficulty in finding an attractive place to eat. In fact, the research area could be an attractive place for tourist due to the inheritance objects. Moreover, the high land value and the strategic location could make these places have a high value as well. The dynamics of culture and heritage had given special meaning in the soul of tourists even just through a traditional food (Doorne et al., 2003).

The distinctive local product sold will create the different perception to respondents. However, the results from the survey indicates that the diversity and choice of selling local product in research area are not various: Maimoon Area, local people (3.58), tourists (3.42), Kesawan Area, local people (3.73), tourists (3.57); and Merdeka Square Area, local people (3.62), tourists (3.73) (Table 2). Even though, more local products could be sold to tourist as an image of Medan City that has nine ethnics (Javanese, Chinese, Bataknese, Karonese, Dairinese, Mandailingnese, Malay, Pakpaknese, and Padangnese), diversity of raw materials, and culture. The diversity local product will create a vibrant atmosphere that is the main attraction toward support in tourism.

\subsubsection{Different Perception}

Cultural activity is one of the primer elements of tourism (Jansen-verbeke, 1986). The diversity of cultural values can be used to attract tourists to come, so they get a distinctive and particular experience. Based on the result, respondents were not impressed with the cultural activity held in research area: Maimoon Area, local people (3.68), tourists (3.75); Kesawan Area, local people (3.88), tourists (3.62); Merdeka Square, local people (3.50), tourists (3.75) (Table 2). In Maimoon Area, Ramadhan Fair was held during Ramadhan since 2004 (Figure 3).

Ramadhan Fair became one of the tourist attractions in the research area. It is a celebration of culinary, accompanied by an exhibition of Small and Medium Enterprises (SMEs), and Muslim performances. During this festival, it often brings actors or singers, both local and national level. This is supported based on the results of interviews with key respondents: 
"The cultural celebration held is diversity and fascinating. One example of a cultural celebration that often attracts tourists is Ramadhan Fair, which is held annually during the fasting month. This festival attracts a lot of tourists who will visit this area".

(Key Respondent: Chairman of INCCA (Indonesian Congress and Convention Association) of North Sumatera)

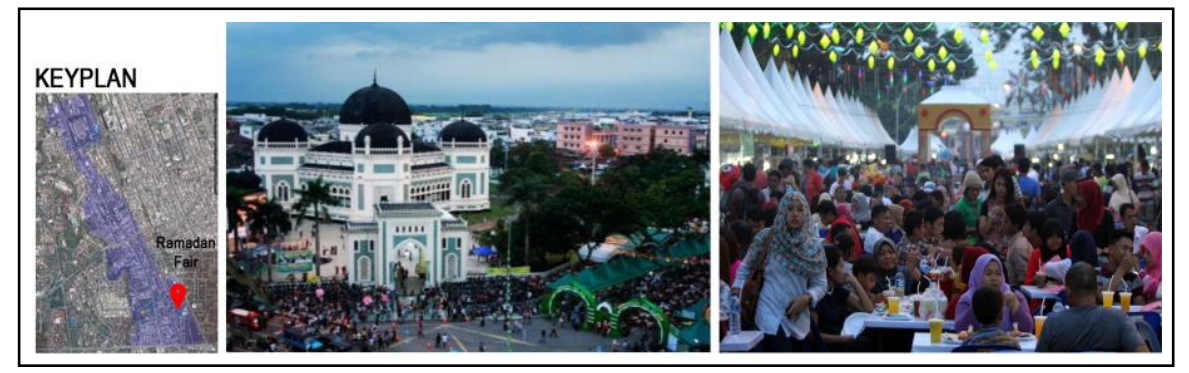

Fig. 3. Ramadhan Fair in Maimoon Area

However, the cultural activity is still not scheduled well that creates a negative perception of tourist. It should become a unique performance for tourists. It is supported with depth interview:

\footnotetext{
"The cultural activity is interesting, but the information is not still widely informed to tourist about the location and the schedule of the cultural activity. Moreover, the unscheduled performance makes it difficult to promote to tourists".

(Key Respondent: Chairman of ASITA (Association of the Indonesian Tours and Travel Agent) of North Sumatera)
}

Thus, the government should improve existing activities so that it is more organized and attractive. The wellscheduled cultural activities will provide a place for tourists to visit and learn about the local culture; this is an element where heritage tourism should belong (Orbaşli, 2000). The events or festival will be a cultural attraction for tourists (Getz, 1991 in (Boyd, 2002)).

The result indicates that respondents have a negative perception of facilities of tourism: Maimoon Area, local people (3.67), tourists (3.67); Kesawan area, local people (3.87), tourists (3.63); and Merdeka Square area, local people (3.62), tourists (3.67). This caused people feel uncomfortable and did not feel safe while visiting. In fact, the facility is a secondary element of tourism (Jansen-Verbeke, 1986).

\section{Conclusion}

A place has an identity when it has elements of distinctiveness or uniqueness so it can be distinguished from other places in the world (Twigger-ross \& Uzzell, 1996). In this case, someone's perception of the uniqueness should be positive (Paumier, 2004). The previous researches (Breakwell, 1986; Lalli, 1992; Lynch, 1960) argued landmark, uniqueness, and particular character as distinctiveness variables but in the current research, authors recommend "different perception" as one of distinctiveness variables that reflect certain image of a place as well. All variables indicate the positive perception that should be supported by the physical or tangible object as well as a unique and memorable element in the research area and its surroundings. Moreover, in defining place identity, the aspects of place identity should balance.

Place identity is an urgent issue to be considered in the planning and design of heritage tourism. This is in line with the global movement to protect places that have a cultural heritage, thereby potentially become a heritage tourism destination. Based on the result, the authors found that distinctiveness aspect contributes in embedding the place identity in Maimoon Area, Kesawan Area, and Merdeka Square through the existence of interesting historic buildings which reflect the local character of an urban and defining distinctiveness aspect. It indicates the image or perception of people as the landmark of Medan City. It also should emphasize on the meaning and significance of the place. However, in this case, the government also should take initiative efforts toward support heritage tourism.

The difference would cause residents and tourists have a special affiliation with the environment that is clearly different from other affiliations (Twigger-ross \& Uzzell, 1996). The particular affiliation is an important factor in 
tourism. It will give a positive attitude to tourists and create a certain image of a place or even a country (Pritchard \& Morgan, 2001). Then, the image will indicate the spirit of place.

Although this research has evaluated the distinctiveness aspect and how it affects or influences heritage tourism but the issue relating to the physical changes in the research area demand further research. It may affect the distinctiveness aspect and other aspects of place identity. Hence, Authors encourage further research of other place identity aspects in defining place identity of an urban area and its influences on place identity. Furthermore, further research of spatial planning based on the place identity would be conducted where the current research can be used as a key guide in planning appropriate effort in maintaining place identity.

\section{Acknowledgment}

The authors wish to record an acknowledgment to the students of Architecture's Department involved in, for the ongoing support and University of Sumatera Utara, Indonesia for the grant support.

\section{References}

Azhari, N. F. N., \& Mohamed, E. (2012). Public Perception: Heritage Building Conservation in Kuala Lumpur. Procedia - Social and Behavioral Sciences, 50, 271-279. https://doi.org/10.1016/j.sbspro.2012.08.033

Boyd, S. (2002). Cultural and Heritage Tourism in Canada: Opportunities, Principles and Challenges. Tourism and Hospitality Research, 3(3), 211-233. https://doi.org/10.1177/146735840200300303

Breakwell, G. M. (1986). Coping with Threatened Identities.Vol. 904. Methuen.

Buiskool, D. A. (2004). Medan: A Plantation City on the East Coast of Sumatera 1870-1942 : Planters ... - Dirk A. Buiskool - Google Buku. Surabaya.

Butler, R., Hall, C. M., \& Jenkins, J. M. (John M. (1998). Tourism and recreation in rural areas. Chichester: Wiley.

Cheshmehzangi, A., \& Heat, T. (2012). Urban Identities: Influences on Socio-Environmental Values and Spatial Inter-Relations. Procedia Social and Behavioral Sciences, 36, 253-264. https://doi.org/10.1016/j.sbspro.2012.03.028

Creswell, J. W. (1994). Research design : qualitative \&amp; quantitative approaches. Sage Publications.

Doorne, S., Ateljevic, I., \& Bai, Z. (2003). Representing identities through tourism: encounters of ethnic minorities in Dali, Yunnan Province, People's Republic of China. International Journal of Tourism Research, 5(1), 1-11. https://doi.org/10.1002/jtr.404

Ginting, N., \& Wahid, J. (2015). Exploring Identity's Aspect of Continuity of Urban Heritage Tourism. Procedia - Social and Behavioral Sciences, 202, 234-241. https://doi.org/10.1016/j.sbspro.2015.08.227

Hussain, K. A. M., \& Ujang, N. (2014). Visitors' Identification of Landmarks in the Historic District of Banda Hilir, Melaka, Malaysia. Procedia - Social and Behavioral Sciences, 153, 689-699. https://doi.org/10.1016/j.sbspro.2014.10.100

Ismagilova, G., Safiullin, L., \& Gafurov, I. (2015). Using Historical Heritage as a Factor in Tourism Development. Procedia - Social and Behavioral Sciences, 188, 157-162. https://doi.org/10.1016/j.sbspro.2015.03.355

Jacobs, J. (2002). The death and life of great American cities. New York: Random House.

Jansen-Verbeke, M. (1986). Inner-city tourism: Resources, tourists and promoters. Annals of Tourism Research, 13(1), 79-100. https://doi.org/10.1016/0160-7383(86)90058-7

Kalandides, A. (2011). The problem with spatial identity: revisiting the "sense of place." Journal of Place Management and Development, 4(1), 28-39. https://doi.org/10.1108/17538331111117142

Lalli, M. (1992). Urban-related identity: Theory, measurement, and empirical findings. Journal of Environmental Psychology, 12(4), $285-303$. https://doi.org/10.1016/S0272-4944(05)80078-7

Lynch, K. (1960). The image of the city. MIT Press. Retrieved from https://books.google.co.id/books/about/The_Image_of_the_City.html?id=_phRPWsSpAgC\&redir_esc=y

Mutfianti, R. D. (2013). Mengembalikan Spirit of Place, Sebuah Upaya mempertahankan Citra Koridor Jalan Tunjungan Surabaya. E-Jurnal EcoTeknologi UWIKA (eJETU), (Vol 1, No 1 (2013)).

Norberg-Schulz, C. (1980). Genius loci : towards a phenomenology of architecture. New York: Rizzoli.

Orbaşli, A. (2000). Is Tourism Governing Conservation in Historic Towns? Journal of Architectural Conservation, 6(3), 7-19. https://doi.org/10.1080/13556207.2000.10785276

Otto, J. E., \& Ritchie, J. R. B. (1996). The service experience in tourism. Tourism Management, 17(3), 165-174. https://doi.org/10.1016/02615177(96)00003-9

Paumier, C. B. (2004). Creating a vibrant city center : urban design and regeneration principles. Washington, D.C.: Urban Land Institute.

Pritchard, A., \& Morgan, N. J. (2001). Culture, identity and tourism representation: marketing Cymru or Wales? Tourism Management, 22(2), 167-179. https://doi.org/10.1016/S0261-5177(00)00047-9

Proshansky, H. M. (1978). The City and Self-Identity. Environment and Behavior, 10(2), 147-169. https://doi.org/10.1177/0013916578102002

Proshansky, H. M., Fabian, A. K., \& Kaminoff, R. (1983). Place-identity: Physical world socialization of the self. Journal of Environmental Psychology, 3(1), 57-83. https://doi.org/10.1016/S0272-4944(83)80021-8

Riza, M., Doratli, N., \& Fasli, M. (2012). City Branding and Identity. Procedia - Social and Behavioral Sciences, 35, $293-300$. https://doi.org/10.1016/j.sbspro.2012.02.091

Samimi, A. J., Sadeghi, S., \& Sadeghi, S. (2011). Tourism and Economic Growth in Developing Countries: P-VAR Approach. Middle-East Journal of Scientific Research, 10(1), 28-32. 
Stratan, A., Perciun, R., \& Gribincea, C. (2015). Identifying Cultural Tourism Potentials in Republic of Moldova through Cultural Consumption among Tourists. Procedia - Social and Behavioral Sciences, 188, 116-121. https://doi.org/10.1016/j.sbspro.2015.03.346

Twigger-ross, C. L., \& Uzzell, D. L. (1996). PLACE AND IDENTITY PROCESSES. Journal of Environmental Psychology, 16(3), $205-220$. https://doi.org/10.1006/jevp.1996.0017

Ujang, N. (2012). Place Attachment and Continuity of Urban Place Identity. Procedia - Social and Behavioral Sciences, 49, $156-167$. https://doi.org/10.1016/j.sbspro.2012.07.014

Wang, S., \& Xu, H. (2015). Influence of place-based senses of distinctiveness, continuity, self-esteem and self-efficacy on residents' attitudes toward tourism. Tourism Management, 47, 241-250. https://doi.org/10.1016/j.tourman.2014.10.007

White, D. D., Virden, R. J., \& van Riper, C. J. (2008). Effects of Place Identity, Place Dependence, and Experience-Use History on Perceptions of Recreation Impacts in a Natural Setting. Environmental Management, 42(4), 647-657. https://doi.org/10.1007/s00267-008-9143-1 